\title{
ERRATA
}

No artigo "AVALIAÇÃO DAFUNÇÃOHIPERBÓLICATRUNCADAPARAADESCRIÇÃODADISTRIBUIÇÃO DIAMÉTRICA DE POVOAMENTOS DESBASTADOS DE EUCALIPTO”, publicado no número 6, volume 38, da Revista Árvore, na página 1037, onde se lê:

${ }^{1}$ Recebido em 03.21.2012 aceito para publicação em 02.07.2014.

\section{Leia-se :}

${ }^{1}$ Recebido em 21.03.2012 aceito para publicação em 02.07.2014. 